\title{
Defining service innovation: A review and syntesis
}

Lars Witell, Hannah Snyder, Anders Gustafsson, Paul Fombelle and Per Kristensson

\author{
Journal Article
}

\section{Tweet}

N.B.: When citing this work, cite the original article.

Original Publication:

Lars Witell, Hannah Snyder, Anders Gustafsson, Paul Fombelle and Per Kristensson, Defining service innovation: A review and syntesis, Journal of Business Research, 2016. 69(8), pp.28632872.

http://dx.doi.org/10.1016/j.jbusres.2015.12.055

Copyright: Elsevier

http://www.elsevier.com/

Postprint available at: Linköping University Electronic Press

http://urn.kb.se/resolve?urn=urn:nbn:se:liu:diva-126537

(c)

1.UU UNWENGES 
Defining service innovation: A review and synthesis

Lars Witell, Service Research Center, Karlstad University and Business Administration, Linköping University, lars.witell@liu.se

Hannah Snyder, Logistics and Quality Management, Linköping University, hannah.snyder@liu.se

Anders Gustafsson, Service Research Center, Karlstad University, and BI - Norwegian School of Management, anders.gustafsson@kau.se

Paul Fombelle, College of Business Administration, Northeastern University, p.fombelle@neu.edu

Per Kristensson, CTF - Service Research Center, Karlstad University, per.kristensson@kau.se

Submission: November 2015

Revision: December 2015

Acceptance: December 2015 


\begin{abstract}
Research on service innovation appears in several research disciplines, with important contributions in marketing, management, and operations research. Although the concept is widely used, few research papers have explicitly defined service innovation. This dearth of research is the motivation for the present study. Through a systematic review of 1301 articles on service innovation appearing in academic journals between 1979 and 2014, this article examines research defining service innovation. The study identifies the key characteristics within 84 definitions of service innovation in different perspectives (assimilation, demarcation and synthesis) and shows how the meaning of the concept is changing. The review suggests that the large variety in definitions limits and hinders knowledge development of service innovation.
\end{abstract}

Keywords: service innovation, literature review, innovation, and value creation 


\section{Introduction}

An increased focus on service innovation is reflected in academic research (Dotzel, Shankar, \& Berry, 2013; Ordanini \& Parasuraman, 2010) through an increased number of publications and interest from diverse research disciplines (Carlborg, Kindström, \& Kowalkowski, 2014; Toivonen \& Tuominen, 2009). However, the concept of service innovation is broad and loosely defined and needs to be further explored and developed (Ostrom et al., 2010). The definition of service innovation is especially problematic because no common understanding exists regarding what it is and entails (Flikkema, Jansen, \& Van Der Sluis, 2007; Toivonen \& Tuominen, 2009).

Theory building on service innovation is still novel (Flikkema et al., 2007), which explains the rather vague and dispersed definitions of the core concept. For example, this vagueness can be seen in the interchangeable use of new service development (NSD) and service innovation (Menor, Tatikonda, \& Sampson, 2002). In addition, the term service innovation is also used to acknowledge a new service, that is, an invention that has not been successfully introduced on the market (Schumpeter, 1934). Also, contrasting views exist regarding how new an innovation needs to be (Toivonen and Tuominen, 2009) and on how to evaluate the value of an innovation (Skålén, Gummerus, Koskull, \& Magnusson, 2014). By investigating how different definitions of service innovation address these issues, the vagueness of the service innovation concept can be analyzed.

Through a systematic literature review, this study examines seemingly divergent perspectives of service innovation and identifies unique and shared characteristics in definitions of service innovation. The commonly used assimilation, demarcation, and synthesis perspectives on service innovation (Coombs \& Miles, 2000) claim to be separate and distinct, and this study aims to identify how the definitions of service innovation have developed across perspectives. This article presents an exhaustive examination of research on 
service innovation, particularly research that addresses the problem of conceptualizing and defining service innovation. The basis of the article is a literature review of service innovation research published in academic journals between 1979 and 2014. These articles range across such disciplines as service management, marketing, business, social science, engineering, and health care research. The study uses network analysis and text mining to identify how research defines service innovation and discusses how the definitions of service innovation have developed on four issues (a process or outcome, invention versus innovation, new for whom and exchange value versus use value) across perspectives.

\section{Defining service innovation}

\subsection{Different perspectives in service innovation research}

As previously mention, to identify the differences in basic assumptions about service innovation, Coombs and Miles (2000) categorized existing research into three different perspectives: assimilation, demarcation, and synthesis. Studies using the assimilation perspective are the most numerous (Gallouj, 2002) and focus on the impact of new technology, which early studies considered the main driver of service innovation (Tether, 2005; Toivonen \& Tuominen, 2009). The assimilation perspective can be used to study and analyze service innovation by using and adapting the same theories and instruments developed for traditional product innovation research, but without translation or modification (e.g., Evangelista, 2000; Miozzo \& Soete, 2001). An important assumption of this perspective is that the service sector is becoming more technology- and capital-intensive (Gallouj \& Savona, 2008). The assimilation approach can be traced back to Pavitt’s (1984) sectorial taxonomy for innovation, in which services are supplier-dominated; in other words, service firms are passive recipients of innovations from other sectors.

The demarcation perspective, by contrast, suggests that service innovation fundamentally differs in nature and character from product innovation (Coombs \& Miles, 2000). This 
perspective challenges the theoretical foundation for innovation studies (Drejer, 2004) and argues for new service-specific theories and concepts with which to understand and analyze service innovation (Barras, 1986; Hipp \& Grupp, 2005; Tether, 2005). Demarcation researchers argue that studies on innovation have failed to recognize the specificities of services and have overlooked the important contributions that service make to products (Gadrey, Gallouj, \& Weinstein, 1995). In particular, demarcation studies illuminate important elements that previous research has neglected (Drejer, 2004; Droege, Hildebrand, \& Forcada, 2009). Research has emphasized the peculiarities of service output and processes, such as the intangible nature of services, the need for customer integration, and the contributions of organizational knowledge and non-technological elements (Hipp \& Grupp, 2005). Drejer (2004) argued that one of the most important contributions of the demarcation perspective is the expansion of what can be considered an innovation.

The synthesis perspective is a critique of both the assimilation and the demarcation perspectives of service innovation (Coombs \& Miles, 2000; Gallouj \& Savona, 2008). The main idea of this perspective is that theories on service innovation should be broad enough to encompass innovation in both services and manufacturing (Coombs \& Miles, 2000) and should provide an integrative perspective that is not limited to technological innovations. The neo-Schumpeterian view of service innovation (e.g., Drejer, 2004; Flikkema et al., 2007; Sundbo, 1997; Toivonen \& Tuominen, 2009) stresses that economic development is driven by the emergence of new combinations (innovations) that are economically more viable than previous solutions.

Even though all of these perspectives clearly contribute to the development of the broad research field of service innovation, one can argue that the differences in defining the concept and the understanding of what a service innovation is create confusion. Different perspectives of what service innovation entail and lead to different actions and use of different methods, as 
will be described in the next section.

\subsection{Divergence about the definition of service innovation}

Well-developed definitions are essential to scientific theory building (MacInnis, 2011; MacKenzie, 2003). MacKenzie (2003) stated that a major shortcoming of many research articles is that they fail to adequately define the focal concept(s) of the study. A definition can be seen as a statement that captures the meaning, the use, and the function of a term or concept (MacInnis, 2011). Precisely defining and labeling constructs is fundamental for knowledge sharing and perspective taking and enables others to understand the theory and be able to criticize and reproduce the observations. MacKenzie (2003) argued that a good definition should specify the concept's conceptual theme in unambiguous terms in a manner that is consistent with prior research and that clearly distinguishes it from related concepts. Failure to define a concept can produce a series of subsequent problems. A theoretical definition must also be followed by an operational definition that translates the verbal meaning into a prescription for measurement to enable empirical research. Poor conceptualization makes it difficult to develop proper measurements and specify relationships between different concepts, which can undermine the study's credibility. Failure to specify the meaning of a particular concept leaves room for misunderstanding, vagueness, and doubt about the quality of the study.

The debate about what an innovation is and how to define it goes back almost a century (Schumpeter, 1934). Independent of conceptualization, articles differ greatly regarding what service innovation is and how it is used. Building on a Schumpeterian approach, Toivonen and Tuominen (2009 p. 893) defined service innovation as “a new service or such a renewal of an existing service which is put into practice and which provides benefit to the organization that has developed it; the benefit usually derives from the added value that the renewal provides the customers. In addition, to be an innovation the renewal must be new not 
only to its developer, but in a broader context.” This definition highlights some interesting aspects of service innovation. First, the definition separates the outcome of service innovation from the process of development. Second, for an invention to become an innovation, it must be used and put into practice. Third, the invention must be new to one of the actors. Fourth, the invention must create value for some actor. In the following, these four issues will be discussed in detail.

Frequently, researchers do not make it clear whether they are using the concept of innovation to refer to the innovation process or to the outcome of this process (Toivonen \& Tuominen, 2009). Literature on new service development (NSD) commonly views service innovation as a process and often uses the terms NSD and service innovation interchangeably (Menor et al., 2002). For example, Biemans, Griffin, and Moenaert (2015, p. 2) stated that one should view NSD and service innovation as synonymous; they defined both concepts as a "process of devising a new or improved service, from idea or concept generation to market launch”. Furthermore, Skålén et al. (2014) argued that the process of developing new services cannot be separated from the implementation and value creation of the new services, and that the two should be seen as different stages of service innovation. In this sense, Skålén et al. (2014) extended the definition of service innovation to include development and realization as well as the outcome. However, doing so creates confusion when talking about successful service innovation, since it is not clear if this statement refers to the successful process or outcome.

Schumpeter (1934) viewed innovation as a novel combination of new and existing knowledge, which should be clearly distinguished from inventions. Schumpeter argued that to differentiate the new offering from the process of its commercialization and the evaluation of the outcome. While an invention can refer to any new product, service, process, or idea, an invention must be introduced in the market and make a substantial profit before it can be 
considered an innovation because inventions in themselves have no inherent value. Gummesson (2014) argues that commercialization and diffusion of inventions is of more value to firms and societies than the initial invention. As a consequence, there is a need to distinguish between inventions and innovations.

Interesting differences occur in the interpretation of “new”. Schumpeter (1934) argued that innovation not only creates value for the firm that developed it, but also changes the market in such a way that other companies imitate and follow, which leads to development of the branch. While this view of newness is fairly strict, recent developments in the service innovation literature have departed from this view towards regarding new as the degree of newness. Defining innovation based on the degree of newness or novelty is now a common way to categorize innovation (Sundbo, 1997; Toivonen \& Tuominen, 2009). A common separation is to divide innovations into radical and incremental, where radical usually refers to innovations that are new to the world and incremental innovations are those that are new to the market (Sundbo, 1997). Following this view, innovations that are only new to the firm that adopts them should not be considered as innovations. Helkkula (2010) stated that companies and other external actors cannot independently decide whether something is an innovation. This issue was also raised by Hipp and Grupp (2005), who identified that firms have difficulty distinguishing between "real” innovations and incremental customer adaptions.

Traditionally, the benefit of innovations is measured in economic value for the developing firm, although this has changed in recent definitions. Consequently, some researchers who view service innovation as outcome or change instead define value from the customer perspective (Lusch \& Nambisan, 2015; Michel, Brown, \& Gallan, 2008). The main argument for this change is that defining innovation in the form of economic value for the developer provides a limited view of what an innovation is. Even if a new service creates 
significant benefits for customers, the service might not generate revenue to the developer. For example, innovation in health care might actually generate increased costs for the developer or society, but can still improve well-being for a patient and provide substantial value to individuals and society. In addition, there is a growing trend for innovations that others can use free of charge, where the benefit for the developer is the intrinsic enjoyment of creating and peer acknowledgment, rather than monetary value (von Hippel, 2005).

Following the debate on the definition of service innovation through the four issues raised above, one could argue that service innovation is likely to be the result of a number of components, contextual aspects, actors, and interactions (Toivonen \& Tuominen, 2009).

Consequently, innovation research should take a broad perspective of the process for determining what an innovation is. However, a broad definition of service innovation should not be misinterpreted as a vague definition as the latter makes it difficult to know what objects is being studied. Of course, a better understanding and knowledge of the crafting of innovations is essential, both for companies wanting to innovate and theory building. However, this fact does not imply that considering and defining the outcome of this process is less important. In the following section, the present review and analysis of definitions of service innovation used in articles from 1979 to 2014 is presented.

\section{Research method}

This study used a systematic literature review to identify articles that define or conceptualize the concept of service innovation. In line with MacInnis’s (2011) framework for conceptual contributions in marketing, the analysis involves differentiating between perspectives of service innovation. Such a distinction provides a typological framework that illustrates how entities (definitions and articles) are different by revealing the underlying key characteristics of the different perspectives of service innovation. The present study examines not only how 
the three perspectives are unique, but also what they have in common and whether an emergent perspective of service innovation can be identified.

\subsection{Search Strategy}

The review identified relevant articles (Tranfield, Denyer, \& Smart, 2003), which enabled a transparent, documented research process with criteria for including and excluding articles. The systematic review involved the following steps: State research questions, develop guidelines for collecting literature, decide on inclusion and exclusion criteria, develop a comprehensive search plan for finding literature, develop a codebook for classifying and describing literature, code the literature, and synthesize the literature (Tranfield et al., 2003).

The present study explores the various ways in which service innovation has been defined in the literature in order to determine whether the three perspectives differ in their definitions. The main search strategy identified research articles that defined the concept of service innovation. In order to capture this, inclusion and exclusion criteria were developed. The initial inclusion criteria were broad to ensure that all relevant articles were identified, were peer-reviewed empirical or conceptual articles, were published in English, and were fully accessible and that the main focus was on service innovation or included a definition of service innovation.

A database search was conducted to find articles that contained the following terms in their abstract, title, or keywords: "service(s) innovation” and “innovation in service(s).” The scope of the search was not limited to any particular field, subject of research, or journal so that a full overview of service innovation research could be obtained. However, closely related terms such as service development, was purposely not included (Menor et al., 2002). In other words, this article focuses on defining service innovation as an outcome, not solely as the development process. 


\subsection{Sample Selection}

The initial search yielded 1301 empirical or conceptual articles, 1003 of which were in English. Figure 1 provides an overview of the literature. All articles were scanned for relevance, which revealed two clear trends. First, although many of the articles used the term "service innovation" in the abstract, few actually defined, conceptualized, or emphasized the term. Second, many of those articles that did specifically focus on service innovation did not provide a specific definition of the concept. This lack of a definition provides further merit to our claim that a clear understanding of service innovation is missing in the literature. In total, 300 articles that had a clear focus on service innovation were selected for further analysis.

Figure 1 here.

Two authors independently read the selected 300 articles to ensure that they met the inclusion criteria and to identify those that defined or conceptualized service innovation. Those authors compared and discussed the results; in cases of disagreement, a third author was consulted. The final sample included 84 articles that provided at least one of the following: a clear definition, a conceptualization, or an explicit referral to a specific definition or conceptualization of service innovation.

Several articles on the topic of service innovation used alternative terms such as “innovation” (Hertog, Gallouj, \& Segers, 2011) “innovation in services” (Gallouj \& Weinstein, 1997), “service-logic innovation” (Michel et al., 2008) and "experience service innovation” (Fuglsang, Sundbo, \& Sørensen, 2011). Because these terms are used interchangeably to describe innovation in a service context, all was considered to be alternative concepts for service innovation. 


\subsection{Data Analysis}

To analyze the sample of articles, a combination of qualitative content analysis and quantitative analysis was used, which is a method for systematically and objectively evaluating texts (Lombard, Snyder-Duch, \& Bracken, 2002). The analysis was conducted in three steps - classification, coding, and text analysis - using qualitative text mining (Feldman \& Sanger, 2007). Researchers often face the question of how to summarize text and determine what words and concepts are more significant than others. To go further than merely summarize, quantitative text analysis was used so that our review would be more than just descriptive statistics and qualitatively comparing and present definitions. Text mining, also known as text data mining or knowledge discovery from textual databases, refers to the process of extracting interesting and non-trivial patterns or knowledge from text documents (Feldman \& Sanger, 2007). The rationale for this process builds on social network theory, which describes linkages among social entities or nodes in a network and the implications of these linkages and can be used on text to determine which words are significant (Xie, 2005). Different measures of centrality were used to determine the significance of words in definitions and comparing between different perspectives of service innovation. Centrality refers to the positions of the node (in this case, words) within the text. Generally, the higher the centrality measure, the more significant or central the word is to the corresponding network (text). That is, influential words are identified through their structural position within the formed networks (Xie, 2005).

All selected articles were downloaded and definitions were captured in digital plain-text format. Each article was then coded according to several predetermined variables, such as context, definitions, approach, and type of study (for example, empirical, conceptual) in order to describe the characteristics of the sample. All definitions were then sorted into Coombs and Miles’s (2000) commonly used perspectives of service innovation; namely, assimilation, 
demarcation, and synthesis. This approach served to analyze and classify the literature on service innovation (Drejer, 2004; Droege et al., 2009; Droege, Hildebrand, \& Forcada 2009). Perspectives were identified using a combined strategy to classify definitions on the basis of whether authors explicitly did or did not take a position on one of the perspectives (Droege et al., 2009).

The study analyzed the specific definition of service innovation offered in each article; by "cleaning” the definitions from "service innovation is defined as ..." and focusing only on the words included in the actual definition of the concept. In addition, all common words such as “and” or "of” were removed. All text were stemmed, a procedure that involves reducing all words with the same stem to a common form (Lovins, 1968). By using this method, the key characteristics for the definitions of each perspective were identified, summarized and visualized.

\section{Findings}

Of 84 the articles in the final sample, eleven used an assimilation perspective, 38 used a demarcation perspective, and 35 used a synthesis perspective. This section presents the result of the text analysis, along with a sub-set of illustrative examples of definitions within each perspective.

\subsection{Defining service innovation in the assimilation perspective}

In the assimilation perspective, most articles that defined service innovation used the term “innovation”. This is consistent with the tradition of taking concepts and definitions from product innovation and using them in service research (e.g., Chan, Go, \& Pine, 1998; Ko \& Lu, 2010; Straub, 2011). The researchers applying this approach did not recognize service as a separate category; rather, they used the term “innovation” for products, services, and processes. The most central word in definitions of service innovation within the assimilation perspective was “new” (3.80), followed by product (2.32), process (2.19), organization 
(2.11), service (1.59), and significant (1.40). Combined, this finding indicates that service innovation is viewed as a new product, process, or service that is significantly different from previous offerings. In addition, the terms “organization” (2.11), "benefit” (0.80) and "successful” (0.73) were used, which indicates a focus on outcome or producer of the new service. This is also reflected in the centrality measures for the full-text articles; in addition to "service” (5.06) and "innovation” (4.5), the most central words were "new” (1.96), “firm” (1.86), “risk” (1.24), “management” (1.15), “recourse” (1.11), “process” (1.06), “capability” (1.06), “market” (0.98) and “product” (0.93).

Insert Table 1 and 2 about here.

\subsection{Defining service innovation in the demarcation perspective}

The 38 articles adopting a demarcation used a variety of terms to relate to service innovation. The actual term “service innovation” was most common, followed by “innovation” and a number of terms that were only used once, such as “experience service innovation” (Fuglsang et al., 2011) and “product-related service innovation” (Gebauer et al., 2008). This implies that the demarcation perspective is more diverse than the assimilation perspective, not only for the concepts as such, but also for the interpretation of specific concepts.

The most central words in definitions of service innovation within the demarcation perspective were “service” (6.18), “new” (4.84), “change” (1.51), customer (1.37), “offer” (1.30), “firm” (1.23), and “process” (1.15). Notably, “service” was used 1.22 times in each definition. These measures indicate that a view of service innovation as a new service or new offer that entails some form of change for either the firm or customer. However, definitions within the demarcation perspective put less emphasis on the indented benefit of the innovation. Even if some definitions use the term value "value”, looking at the frequency, this is only used in $17 \%$ of the definitions. In addition, innovation is emphasized as a term in 
the actual definition, as a result of authors using the word "innovation" in different ways. For example, (Lin, 2012) used “innovation activities,” and Carvalho (2010) used “innovation patterns” in their definitions of service innovation. In the full-text articles, in addition to “service” (4.03) and "innovation” (3.18), terms such as “firm” (1.19), “new” (1.1), "market” (0.94), “management” (0.89), “customer” $(0.8)$ were the most central words.

Even if this still suggests an internal focus in terms of firm and management, in comparison to the assimilation perspective, the centrality of customers is emergent both in definition and full text.

Insert Table 3 and 4 about here

\subsection{Defining service innovation in the synthesis perspective}

The synthesis perspective includes 35 articles that defined service innovation. "Service innovation” and "innovation” were the two most used concepts, followed by concepts that were only used in individual studies, such as "health-service innovation" (Windrum \& García-Goñi, 2008) “service-logic innovation” (Michel et al., 2008), “innovation in services” (Sundbo, 1997), and “market-creating service innovation” (Berry et al., 2010). The greater reliance on the concepts of service innovation and innovation is consistent with the purpose of the synthesis perspective, which is to encompass all types of innovation.

The most central word in definitions of service innovation within the synthesis perspective was “service” (3.23), followed by "new” (2.78), “change” (1.4), “customer” (1.35), "product” (1.2), and “process” (1.18). Similarly to the demarcation perspective, the centrality measures indicate that service innovation is viewed as a new service, product or process that implies some degree of change for the customer. However, within definitions of service innovation in the synthesis perspective, the emphasis on the benefit is slightly higher as both "value" (0.64) and "benefit" $(0.63)$ is put forward. This point also emerges in the in 
full text; in addition to the centrality of "service" (4.08) and "innovation" (3.81), the terms “firm” (1.43), “new” (1.07), “customer” (0.89), “process” (0.83), “market” (0.76), “knowledge” (0.67), “product” (0.64) and “value” (0.59) were identified as the most central words.

Insert Table 5 and 6 about here

\section{Discussion}

\subsection{A shared view of service innovation as a new service}

The view of service innovation as a new service (offering) cuts across the three perspectives of assimilation, demarcation, and synthesis. In the assimilation perspective, "new" and "service” have the highest centrality measures in the full-text analysis. ,For demarcation and synthesis "new" and "service" come out as the characteristics most central in the definitions (not the full text analysis). Interestingly, the word "new" was used more than once in each definition, on average. It seems that simply defining service innovation as a "new service" is the most common interpretation, which implies that every firm, to some extent, is innovative and develops service innovations. However, viewing service innovation, as a new service is not without problems, since "new" is a relative concept (Toivonen \& Tuominen 2009). A greater emphasis on newness suggests a radical service innovation and newness can mean new to the firm (Mansury \& Love, 2008), new to a market, or new to the world (Mansury \& Love, 2008; Toivonen \& Tuominen, 2009). The conceptualization of service innovation should extend beyond a new service for a firm and put real meaning behind the characteristic “new.” By emphasizing newness, researchers and managers can identify which organizational arrangements are necessary in order to develop radical service innovations. 


\subsection{What characterizes service innovation in assimilation, demarcation, and synthesis} research?

This research questions the suggestions posed by prior research that synthesis is replacing assimilation and demarcation in research on service innovation (Carlborg et al., 2014). Based on our systematic review, the prevalence of the synthesis perspective seems to have been overstated; while the synthesis perspective is growing and gaining strength, the number of articles adopting assimilation or demarcation perspectives has neither decreased nor disappeared. As an example, recent papers have defined service innovation according to the assimilation perspective (e.g., Björk, 2014; Castellacci, 2014; Giannopoulou, Gryszkiewicz, \& Barlatier, 2014; Henrike \& Schultz, 2014), which suggests that the assimilation perspective might even be regaining its strength. In the following, this research will highlight the differences between the definitions of service innovation in the three perspectives and question and explain why the relevance of the service innovation concept might be lost.

Insert Table 7 about here.

To emphasize the differences in perspectives different labels to specify the concept's conceptual theme can be used. The use of the terms "innovation" for assimilation, "services innovation" for demarcation, and "service innovation” for synthesis is consistent with the origin and key characteristics used in each perspective. Labeling the concept to emphasize its characteristics enables researchers to be more stringent in defining and using the service innovation concept and helps make it clearly distinguishable from related concepts (MacKenzie, 2003).

The assimilation perspective involves a technological view of innovation and is driven by the development of new technology that can contribute to the development of significant different offerings (Coombs \& Miles, 2000). In line with Schumpeter (1934), Ko and Lu (2010, p. 164) suggested that innovations are "technology-based inventions, driven by the 
emergence of new markets or new service opportunities.” In other words, the assimilation perspective aligns itself with the Schumpeterian view of innovation, focusing on innovation as an outcome that is new to the world and creates exchange value for the firm. The definitions of innovation signal an internal perspective on innovation, emphasizing key characteristics such as product, process, and organization, and suggesting that an innovation that is technological and significantly different from an existing to a new solution should have economic consequences for the firm. This type of definition can explain the emergence of better online banking or search engines, but it only tells part of the story.

The demarcation perspective works well for understanding innovation in specific industries, such as health care, retailing, and tourism. The key characteristics revealed by the text analysis are change, customer, offer and firm. The firm and customer dichotomy shows a traditional view of the different actors in value creation; namely, that service innovations appear in a business relationship between two actors. Den Hertog, Gallouj, and Segers (2011, p. 1436) argued that a service innovation can be described as "a new or considerably changed (new to the firm) product or service ... or introduced a new or considerably changed (new to the firm) process innovation.” In the demarcation perspective, the definition of service innovation starts to break free from an Schumpeterian view of innovation in that it concerns the outcome, but focuses on inventions that are new to the firm. This definition suggests that the change in the offering does not need to be substantially new, introduced in the market, or make a substantial profit in order to be considered a service innovation. In practice, this means that all service firms develop service innovations.

Theories and methods of service innovation in the synthesis perspective depart from a service logic (Michel et al., 2008). In particular, the key characteristics in the definitions of service innovation are viewed as change, customer, product, process, exist, more, and value. This perspective implies a value proposition as a platform for value cocreation in the 
customer context and that both product and process can be part of the value proposition offered to customers as a service innovation (Skålen et al., 2014). Cullen (2008, p. 255) described service innovation as being "created with a particular value proposition in mind, which enables the user of the service to create value for themselves or their community.” Schumpeter has influenced the synthesis perspective, but in certain aspects its conceptualization of service innovation moves away from the original ideas. While Schumpeter (1934) argued that the process of developing a new offering should be differentiated from the process of its commercialization and evaluation of the outcome, a synthesis perspective views service innovation as both the development process and its outcome. Skålén et al. (2014 p.137) defined service innovation as "the creation of new value propositions by means of developing existing or creating new practices and/or resources, or by means of integrating practices and resources in new ways.” The interpretation of a service innovation in this sense is that it can be a new development process or its outcome that is new to the firm and creates value in use, but does not have to be introduced on the market. The lack of precision in the service innovation concept makes it ambiguous and does not distinguish it from related concepts such as new service development.

\subsection{Implications for research and practice}

This systematic review of existing research on service innovation makes a contribution to understanding what a service innovation is. Previous literature reviews on service innovation have performed qualitative (e.g., Carlborg et al., 2014) or descriptive (Biemans et al., 2015; Papastathopoulou \& Hultink, 2012) analyses, including literature on NSD. To extend previous research, our study uses network analysis and text mining to achieve a detailed understanding of the key characteristics of service innovation. Specifically, this research contributes by identifying the characteristics in the definitions, and the development of the view of service innovation used in assimilation, demarcation, and synthesis perspectives. 
Using network analysis and text mining, this systematic review provides several significant contributions to the theoretical understanding of service innovation.

First, much of the research on service innovation has failed to define the focal concept (MacKenzie, 2003). Although there is, to some extent, a shared view of service innovation as a "new service”, this is an insufficient definition suggesting that all firms develop service innovations. Using a theoretical, practical or policy perspective it is not fruitful to claim that all firms are innovators, since it will not help us to understand how innovations can help to build brands, firms or societies. For example, in the assimilation perspective, innovation often means "radical technical innovation"; in the demarcation perspective, it often means "small process adaption” for a firm; in the synthesis perspective, it often refers to skills in new service development. Sharing an overall view of service innovation enables theory building and research to better operationalize service innovation in further empirical studies.

Second, the present study identifies the key characteristics in definitions of service innovation in each perspective. Product and process exist in definitions across all three perspectives, but have proven insufficient for understanding service innovation (Gallouj \& Savona, 2008). In addition, the definitions of service innovation in each perspective also emphasize unique key characteristics. Definitions in the demarcation perspective introduced the firm and customer dichotomy (Oke, 2007; Gebauer et al., 2008), while definitions in the synthesis perspective started to emphasize value (Skålén et al., 2014). Through introducing new key characteristics in the definition of service innovation, service research has contributed with a broadened perspective on what constitutes an innovation.

Third, Schumpeter (1934) was clear in his distinction between the development process, the outcome, and the commercialization of innovation. However, this distinction seems to have been lost in present research following a demarcation or synthesis perspective on service innovation. These two perspectives often include the development process 
defining the concept of service innovation; and that the commercialization process is ignored through the change of focus from exchange value towards use value. Although, this enables service researchers to identify new traits of service innovation it also hinders further theoretical development since it will not help to explain why some new services become successful and others not.

Different perspectives of service innovation can explain the content and emergence of different types of innovations. Companies simply need to balance their innovation efforts. In this classic dilemma, companies must make trade-offs between exploitation and exploration or incremental and radical innovation if they are to survive, let alone prosper (Brown \& Eisenhardt 1998; Levinthal \& March, 1993). Service innovation adds a new dimension to the balancing effort (Gebauer et al. 2011), and, as seen above, several perspectives are necessary to understand how to succeed with service innovation.

\subsection{Limitations and further research}

The present study has certain limitations. As with other literature reviews in marketing and service management, the study only includes studies published in academic journals and have excluded books and other literature that could have been relevant. In addition, the study only included research on service innovation using our selected search terms in the title, abstract, or keywords. In particular, this limitation could affect the sample of articles taking an assimilation perspective. Literature on innovation might employ an assimilation perspective using services as an example of innovation without using the term "service innovation." Such studies are not included and instead the study focused solely on articles that define the concept of service innovation. As a result, many articles that do not explicitly define service innovation are not included. To advance understanding of service innovation, further research should address these identified shortcomings. 


\section{REFERENCES}

Barras, R. (1986). Towards a theory of innovation in services. Research Policy, 15(4), 161173. http://doi.org/10.1016/0048-7333(86)90012-0

Berry, L. L., Bolton, R. N., Bridges, C. H., Meyer, J., Parasuraman, A., \& Seiders, K. (2010). Opportunities for Innovation in the Delivery of Interactive Retail Services. Journal of Interactive Marketing, 24(2), 155-167. http://doi.org/10.1016/j.intmar.2010.02.001

Biemans, W. G., Griffin, A., \& Moenaert, R. K. (2015). New Service Development: How the Field Developed, Its Current Status and Recommendations for Moving the Field Forward. Journal of Product Innovation Management, n/a-n/a. http://doi.org/10.1111/jpim.12283 Björk, P. (2014). The DNA of Tourism Service Innovation: A Quadruple Helix Approach. Journal of the Knowledge Economy, 5(1), 181-202. http://doi.org/10.1007/s13132-014-0183$\mathrm{x}$

Brown, L., \& Osborne, S. P. (2013). Risk and Innovation: Towards a framework for risk governance in public services. Public Management Review, 15(2), 186-208. http://doi.org/10.1080/14719037.2012.707681

Carlborg, P., Kindström, D., \& Kowalkowski, C. (2014). The evolution of service innovation research: a critical review and synthesis. The Service Industries Journal, 34(5), 373-398. http://doi.org/10.1080/02642069.2013.780044

Carvalho, L. (2010). Innovation Propensity of Multinational Firms in the Service Sector. Journal of Transnational Management, 15(1), 26-45.

http://doi.org/10.1080/15475770903028621

Castellacci, F. (2014). Service innovation and the proximity-concentration trade-off model of trade and FDI. Economics of Innovation and New Technology, 23(1), 92-108.

http://doi.org/10.1080/10438599.2013.828890

Chan, A., Go, F. M., \& Pine, R. (1998). Service Innovation in Hong Kong: Attitudes and 
Practice. The Service Industries Journal, 18(2), 112-124.

http://doi.org/10.1080/02642069800000021

Cheng, C. C., \& Krumwiede, D. (2011). The effects of market orientation on new service performance: the mediating role of innovation. International Journal of Services Technology and Management, 16(1), 49-73.

Chen, J.-S., Hung Tai Tsou, \& Huang, A. Y.-H. (2009). Service Delivery Innovation: Antecedents and Impact on Firm Performance. Journal of Service Research, 12(1), 36-55. http://doi.org/10.1177/1094670509338619

Cho, I., Park, H., \& Kim, J. K. (2012). The moderating effect of innovation protection mechanisms on the competitiveness of service firms. Service Business, 6(3), 369-386. http://doi.org/10.1007/s11628-012-0140-3

Coombs, R., \& Miles, I. (2000). Innovation, Measurement and Services: The New Problematique. In J. S. Metcalfe \& I. Miles (Eds.), Innovation Systems in the Service Economy (pp. 85-103). Springer US. Retrieved from http://link.springer.com/chapter/10.1007/978-1-4615-4425-8_5

Cullen, J. (2008). Catalyzing innovation and knowledge sharing: Librarian 2.0. Business Information Review, 25(4), 253-258. http://doi.org/10.1177/0266382108098059

Dotzel, T., Shankar, V., \& Berry, L. L. (2013). Service Innovativeness and Firm Value. Journal of Marketing Research, 50(2), 259-276.

Drejer, I. (2004). Identifying innovation in surveys of services: a Schumpeterian perspective. Research Policy, 33(3), 551-562. http://doi.org/10.1016/j.respol.2003.07.004

Droege, H., Hildebrand, D., \& Forcada, M. A. H. (2009). Innovation in services: present findings, and future pathways. Journal of Service Management, 20(2), 131-155. http://doi.org/10.1108/09564230910952744 Drucker, P. F. (1985). Innovation and Entrepreneurship Harper \& Row. New York. 
Enz, C. A. (2012). Strategies for the Implementation of Service Innovations. Cornell Hospitality Quarterly, 53(3), 187-195. http://doi.org/10.1177/1938965512448176

Evangelista, R. (2000). Sectoral patterns of technological change in services. Economics of Innovation and New Technology, 9(3), 183-222.

Feldman, R., \& Sanger, J. (2007). The Text Mining Handbook: Advanced Approaches in Analyzing Unstructured Data. Cambridge University Press.

Ferreira, J. J. M., Raposo, M. L., \& Fernandes, C. I. (2013). Does innovativeness of knowledge-intensive business services differ from other industries? The Service Industries Journal, 33(7-8), 734-748. http://doi.org/10.1080/02642069.2013.740462

Flikkema, M., Jansen, P., \& Van Der Sluis, L. (2007). Identifying Neo-Schumpeterian Innovation in Service Firms: A Conceptual Essay with a Novel Classification. Economics of Innovation \& New Technology, 16(7), 541-558. http://doi.org/10.1080/10438590600918602 Fuglsang, L., Sundbo, J., \& Sørensen, F. (2011). Dynamics of experience service innovation: innovation as a guided activity - results from a Danish survey. The Service Industries Journal, 31(5), 661-677. http://doi.org/10.1080/02642060902822109

Gadrey, J., Gallouj, F., \& Weinstein, O. (1995). New modes of innovation: How services benefit industry. International Journal of Service Industry Management, 6(3), 4-16. http://doi.org/10.1108/09564239510091321

Gebauer, H., Krempl, R., Fleisch, E., \& Friedli, T. (2008). Innovation of product-related services. Managing Service Quality, 18(4), 387-404.

http://doi.org/10.1108/09604520810885626

Giannopoulou, E., Gryszkiewicz, L., \& Barlatier, J-P. (2014). Creativity for service innovation: a practice-based perspective. Managing Service Quality: An International Journal, 24(1), 23-44. http://doi.org/10.1108/MSQ-03-2013-0044 
Gummesson, E. (2014). Commentary on "The role of innovation in driving the economy: Lessons from the global financial crisis.” Journal of Business Research, 67(1), 2743-2750. http://doi.org/10.1016/j.jbusres.2013.03.025

Helkkula, A. (2010). Service experience in an innovation context. Helsinki: Hanken School of Economics :

Henrike, H.-W., \& Schultz, C. (2014). The impact of health care professionals' service orientation on patients’ innovative behavior: Health Care Management Review, 39(4), 329339. http://doi.org/10.1097/HMR.0b013e31829d534c

Hertog, P. D., Gallouj, F., \& Segers, J. (2011). Measuring innovation in a "low-tech" service industry: the case of the Dutch hospitality industry. The Service Industries Journal, 31(9), 1429-1449. http://doi.org/10.1080/02642060903576084

Hipp, C., \& Grupp, H. (2005). Innovation in the service sector: The demand for servicespecific innovation measurement concepts and typologies. Research Policy, 34(4), 517-535. http://doi.org/10.1016/j.respol.2005.03.002

Hippel, E. von. (2005). Democratizing innovation: The evolving phenomenon of user innovation. Journal Für Betriebswirtschaft, 55(1), 63-78. http://doi.org/10.1007/s11301-004$0002-8$

Jian, Z., \& Wang, C. (2013). The impacts of network competence, knowledge sharing on service innovation performance: Moderating role of relationship quality. Journal of Industrial Engineering and Management, 6(1). http://doi.org/10.3926/jiem.659

Joachim Breunig, K., Helge Aas, T., \& Maria Hydle, K. (2014). Incentives and performance measures for open innovation practices. Measuring Business Excellence, 18(1), 45-54. http://doi.org/10.1108/MBE-10-2013-0049 Ko, H.-T., \& Lu, H.-P. (2010). Measuring innovation competencies for integrated services in the communications industry. Journal of Service Management, 21(2), 162-190. 
http://doi.org/10.1108/09564231011039277

Kuo, Y.-K., Kuo, T.-H., \& Ho, L.-A. (2014). Enabling innovative ability: knowledge sharing as a mediator. Industrial Management \& Data Systems, 114(5), 696-710.

http://doi.org/10.1108/IMDS-10-2013-0434

Lin, L. (2012). An empirical study on the relationship between service innovation and firm performance based on revised SPC model: evidence from China’s communication industry. International Journal of Services Technology \& Management, 18(3/4), 154-183.

Lin, R.-J., Chen, R.-H., \& Chiu, K. K.-S. (2010). Customer relationship management and innovation capability: an empirical study. Industrial Management \& Data Systems, 110(1), 111-133. http://doi.org/10.1108/02635571011008434

Lombard, M., Snyder-Duch, J., \& Bracken, C. C. (2002). Content Analysis in Mass Communication: Assessment and Reporting of Intercoder Reliability. Human Communication Research, 28(4), 587-604. http://doi.org/10.1111/j.14682958.2002.tb00826.x

Love, J. H., Roper, S., \& Bryson, J. R. (2011). Openness, knowledge, innovation and growth in UK business services. Research Policy, 40(10), 1438-1452.

http://doi.org/10.1016/j.respol.2011.05.016

Love, J. H., Roper, S., \& Hewitt-Dundas, N. (2010). Service Innovation, Embeddedness and Business Performance: Evidence from Northern Ireland. Regional Studies, 44(8), 983-1004. http://doi.org/10.1080/00343400903401568

Lovins, J. B. (1968). Development of a stemming algorithm. MIT Information Processing Group, Electronic Systems Laboratory.

Lusch, R. F., \& Nambisan, S. (2015). Service Innovation: A Service-Dominant Logic Perspective. MIS Quarterly, 39(1), 155-176.

MacInnis, D. J. (2011). A Framework for Conceptual Contributions in Marketing. Journal of 
Marketing, 75(4), 136-154. http://doi.org/10.1509/jmkg.75.4.136

MacKenzie, S. B. (2003). The dangers of poor construct conceptualization. Journal of the Academy of Marketing Science, 31(3), 323-326.

http://doi.org/10.1177/0092070303031003011

Mansury, M. A., \& Love, J. H. (2008). Innovation, productivity and growth in US business services: A firm-level analysis. Technovation, 28(1-2), 52-62.

http://doi.org/10.1016/j.technovation.2007.06.002

Menor, L. J., Tatikonda, M. V., \& Sampson, S. E. (2002). New service development: areas for exploitation and exploration. Journal of Operations Management, 20(2), 135-157. http://doi.org/10.1016/S0272-6963(01)00091-2

Michel, S., Brown, S. W., \& Gallan, A. S. (2008). Service-Logic innovations: How to Innovate Customers, Not Products. California Management Review, 50(3), 49-65. http://doi.org/10.2307/41166445

Miozzo, M., \& Soete, L. (2001). Internationalization of Services: A Technological Perspective. Technological Forecasting and Social Change, 67(2-3), 159-185. http://doi.org/10.1016/S0040-1625(00)00091-3

Oke, A. (2007). Innovation types and innovation management practices in service companies. International Journal of Operations \& Production Management, 27(6), 564-587. http://doi.org/10.1108/01443570710750268

Ordanini, A., \& Parasuraman, A. (2010). Service Innovation Viewed Through a ServiceDominant Logic Lens: A Conceptual Framework and Empirical Analysis. Journal of Service Research, 14(1), 3-23. http://doi.org/10.1177/1094670510385332

Ostrom, A. L., Bitner, M. J., Brown, S. W., Burkhard, K. A., Goul, M., Smith-Daniels, V., ... Rabinovich, E. (2010). Moving Forward and Making a Difference: Research Priorities for the Science of Service. Journal of Service Research, 13(1), 4-36. 
http://doi.org/10.1177/1094670509357611

Papastathopoulou, P., \& Hultink, E. J. (2012). New Service Development: An Analysis of 27 Years of Research . Journal of Product Innovation Management, 29(5), 705-714. http://doi.org/10.1111/j.1540-5885.2012.00944.x

Pavitt, K. (1984). Sectoral patterns of technical change: Towards a taxonomy and a theory. Research Policy, 13(6), 343-373. http://doi.org/10.1016/0048-7333(84)90018-0

Pearson, R. (1997). Towards an historical model of services innovation: The case of the insurance industry, 1700-1914. The Economic History Review, 50(2), 235-256.

Salunke, S., Weerawardena, J., \& McColl-Kennedy, J. R. (2011). Towards a model of dynamic capabilities in innovation-based competitive strategy: Insights from project-oriented service firms. Industrial Marketing Management, 40(8), 1251-1263.

http://doi.org/10.1016/j.indmarman.2011.10.009

Santamaría, L., Jesús Nieto, M., \& Miles, I. (2012). Service innovation in manufacturing firms: Evidence from Spain. Technovation, 32(2), 144-155.

http://doi.org/10.1016/j.technovation.2011.08.006

Schumpeter, J. (1934). Theories of economic development. Cambridge, MA.

Skålén, P., Gummerus, J., Koskull, C. von, \& Magnusson, P. R. (2014). Exploring value propositions and service innovation: a service-dominant logic study. Journal of the Academy of Marketing Science, 1-22. http://doi.org/10.1007/s11747-013-0365-2

Straub, A. (Ad). (2011). Maintenance contractors acting as service innovators. Construction Innovation: Information, Process, Management, 11(2), 179-189.

http://doi.org/10.1108/14714171111124158

Sundbo, J. (1997). Management of Innovation in Services. The Service Industries Journal, 17(3), 432-455. http://doi.org/10.1080/02642069700000028

Tether, B. S. (2005). Do Services Innovate (Differently)? Insights from the European 
Innobarometer Survey. Industry \& Innovation, 12(2), 153-184.

http://doi.org/10.1080/13662710500087891

Toivonen, M., \& Tuominen, T. (2009). Emergence of innovations in services. The Service Industries Journal, 29(7), 887-902. http://doi.org/10.1080/02642060902749492

Tranfield, D., Denyer, D., \& Smart, P. (2003). Towards a Methodology for Developing Evidence-Informed Management Knowledge by Means of Systematic Review. British Journal of Management, 14(3), 207-222. http://doi.org/10.1111/1467-8551.00375 van der Aa, W., \& Elfring, T. (2002). Realizing innovation in services. Scandinavian Journal of Management, 18(2), 155-171. http://doi.org/10.1016/S0956-5221(00)00040-3 West, M.A. and Farr, J.L. (1990). “Innovation”, Innovation and Creativity at Work: Psychological and Organizational Strategies . New York: John Wiley \& Sons. Windrum, P., \& García-Goñi, M. (2008). A neo-Schumpeterian model of health services innovation. Research Policy, 37(4), 649-672.

Xie, Z. (2005). Centrality Measures in Text Mining: Prediction of Noun Phrases That Appear in Abstracts. In Proceedings of the ACL Student Research Workshop (pp. 103-108). Stroudsburg, PA, USA: Association for Computational Linguistics. Retrieved from http://dl.acm.org/citation.cfm?id=1628960.1628980 


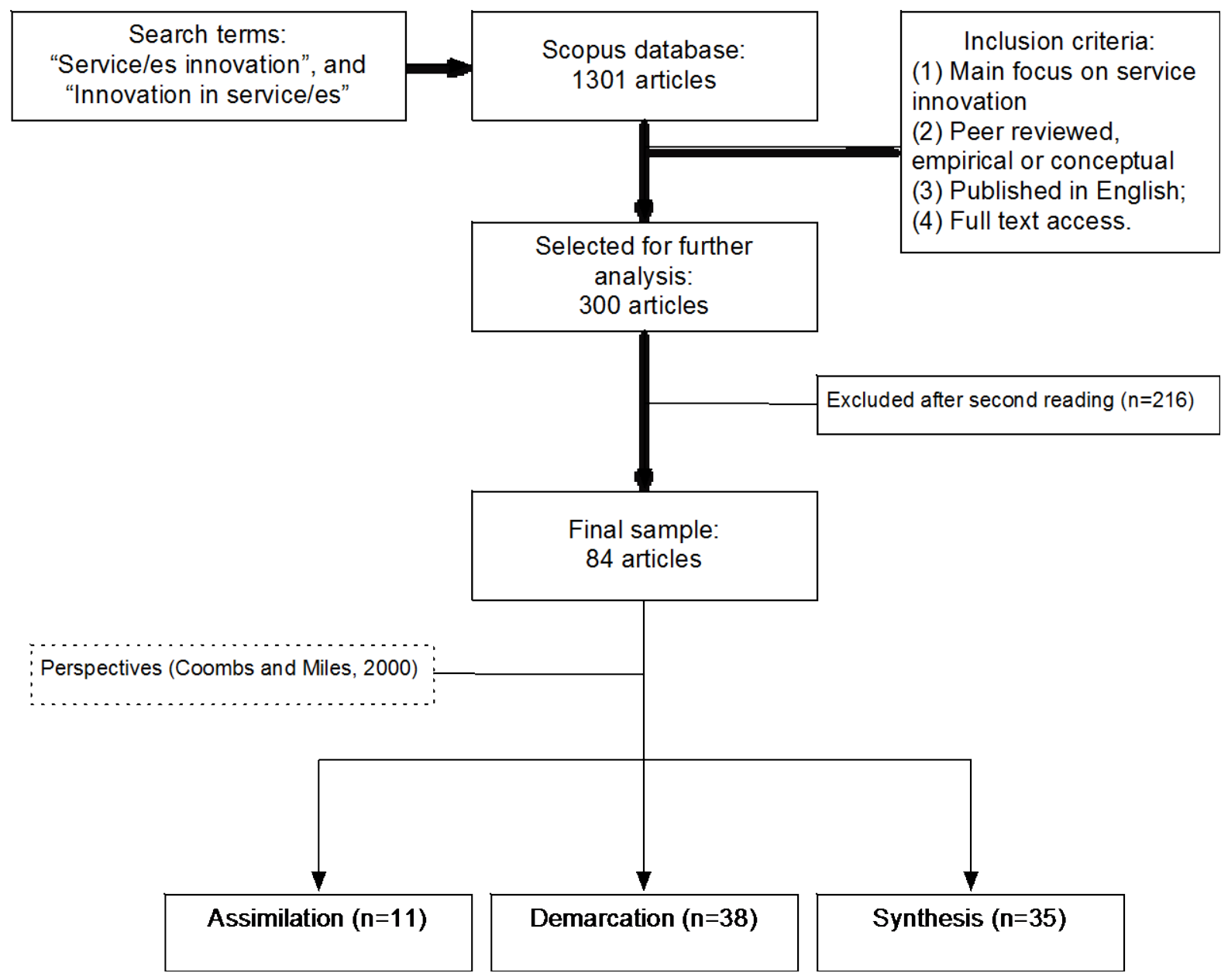

Figure 1 An overview of the literature review 
Table 1 Definitions of service innovation from an assimilation perspective

\section{Assimilation}

Source Term Definition

Pearson (1997) Innovation "Changes in the process of producing existing lines of insurance for example, improvements in risk assessment (new policy conditions, new classifications of existing risks), in marketing, and in organization. Primary product innovation (PPI) can be defined as new products for new risks, which together sometimes constitute new branches of the insurance industry, in the way that, for instance, employers' liability and railway accident insurance formed branches of accident insurance.” (p. 238)

Chan, Go, and Pine (1998) Innovation “The purposeful and organized search for changes, and the systematic analysis of the opportunities such changes might offer for

Ko and Lu (2010) Innovation “Technology-based inventions, driven by the emergence of new markets or new service opportunities. (p. 164)

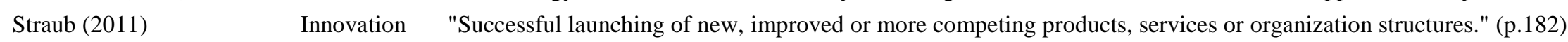

Brown and Osbourn (2013) Innovation "The intentional introduction and application within a role, group or organization of ideas, processes, products or procedures, new to the relevant unit of adoption, designed to significantly benefit the individual, the group organization or wider society." (p.188)**

Ferreira et al. (2013) Innovation "Innovation is the mechanism by which firms design and launch the new products, processes and systems necessary to meeting changes both in marketplace technologies and in models of competition" (p.734)

Björk (2014)

Innovation "New products, services, systems, and processes" (p. 183)

Giannopoulou et al. (2014) Service

Innovation

"A type of product innovation involving the introduction of a service that is new or significantly improved with respect to its characteristics or to its intended uses” (p.25)

Henrike and Schultz (2014) Innovation

Kuo, Kuo, and Ho (2014) Service

"Creation of solutions, which can either be emerging incremental adaptations or completely new solutions for products, services, or processes to significantly benefit the care situation of patients" (p.330)

"A new way of business thinking to reform relatively conservative and inflexible operational

Innovation procedures and processes, which can transform organizations to better meet the needs of their markets " (p.697)

* Adopted from Drucker (1985)

** Adopted from West and Farr (1990) 
Table 2 Centrality measures within assimilation

\begin{tabular}{lccclccc}
\hline \multicolumn{2}{c}{ Definition } & \multicolumn{3}{c}{ Full text } & & \\
\hline Term & Occurrences & Frequency & Centrality & Term & Occurrences & Frequency & 1.1.1.1.1.1.1 Centrality \\
New & 13 & 1.18 & 3.80 & Service & 1501 & 136.46 & 5.06 \\
Product & 6 & 0.55 & 2.32 & Innovation & 1756 & 159.64 & 4.50 \\
Process & 5 & 0.46 & 2.19 & New & 606 & 55.09 & 1.96 \\
Organization & 5 & 0.46 & 2.11 & Firm & 797 & 72.46 & 1.86 \\
Service & 5 & 0.46 & 1.59 & Risk & 417 & 37.91 & 1.24 \\
Significantly & 3 & 0.27 & 1.41 & Management & 460 & 41.82 & 1.15 \\
Design & 2 & 0.18 & 1.23 & Resource & 172 & 15.64 & 1.11 \\
Group & 2 & 0.18 & 1.23 & Process & 369 & 33.55 & 1.06 \\
Idea & 2 & 0.18 & 1.23 & Capability & 135 & 12.27 & 1.06 \\
Introduction & 2 & 0.18 & 1.23 & Market & 311 & 28.27 & 0.98 \\
System & 2 & 0.18 & 1.23 & Product & 322 & 29.27 & 0.93 \\
Change & 4 & 0.36 & 1.07 & Innovative & 241 & 21.91 & 0.83 \\
Market & 3 & 0.27 & 0.91 & Model & 331 & 30.09 & 0.82 \\
Insurance & 4 & 0.36 & 0.82 & Industry & 258 & 23.46 & 0.77 \\
Benefit & 2 & 0.18 & 0.80 & Result & 215 & 19.55 & 0.77 \\
Innovation & 2 & 0.18 & 0.76 & Ability & 110 & 10 & 0.75 \\
Improve & 2 & 0.18 & 0.73 & Offer & 99 & 9 & 0.75 \\
Launch & 2 & 0.18 & 0.73 & Development & 266 & 24.18 & 0.73 \\
Successful & 2 & 0.18 & 0.73 & Activity & 203 & 18.46 & 0.73 \\
Adoption & 1 & 0.09 & 0.63 & System & 206 & 18.73 & 0.72 \\
Application & 1 & 0.09 & 0.63 & Competency & 200 & 18.18 & 0.68 \\
Competition & 1 & 0.09 & 0.63 & Level & 232 & 21.09 & 0.67 \\
Define & 1 & 0.09 & 0.63 & Customer & 130 & 11.82 & 0.67 \\
Domain & 1 & 0.09 & 0.63 & Knowledge & 266 & 24.18 & 0.65 \\
Firm & 1 & 0.09 & 0.63 & Variable & 241 & 21.91 & 0.63 \\
\hline
\end{tabular}


Table 3 Definitions of service innovation from a demarcation perspective

\begin{tabular}{|c|c|c|}
\hline \multicolumn{3}{|r|}{ Demarcation } \\
\hline Source & Term & Definition \\
\hline Oke (2007) & $\begin{array}{l}\text { Service } \\
\text { innovation }\end{array}$ & $\begin{array}{l}\text { "New developments in activities undertaken to deliver core service products for various reasons, e.g. to make those core service } \\
\text { products more attractive to consumers.” (p. 566) }\end{array}$ \\
\hline $\begin{array}{l}\text { Gebauer et al. } \\
\text { (2008) }\end{array}$ & $\begin{array}{l}\text { Product- } \\
\text { related } \\
\text { service } \\
\text { innovation }\end{array}$ & $\begin{array}{l}\text { “An offering not previously available to a firm’s customers, resulting from additions to or changes in the service concept. “ (p. } \\
\text { 388) }\end{array}$ \\
\hline $\begin{array}{l}\text { Chen, Tsou, and } \\
\text { Huang (2009) }\end{array}$ & $\begin{array}{l}\text { Service } \\
\text { delivery } \\
\text { innovation }\end{array}$ & $\begin{array}{l}\text { "May be regarded as novel mechanisms of delivery that offer customers greater convenience and improve a firm’s competitive } \\
\text { position.” (p. 39) }\end{array}$ \\
\hline $\begin{array}{l}\text { Cheng and } \\
\text { Krumwiede } \\
\text { (2010) }\end{array}$ & $\begin{array}{l}\text { Service } \\
\text { innovation }\end{array}$ & "Fundamental change in services that represent revolutionary changes in technology or service benefits.” (p.162) \\
\hline $\begin{array}{l}\text { Lin, Chen and } \\
\text { Chiu (2010) }\end{array}$ & $\begin{array}{l}\text { Service } \\
\text { innovation }\end{array}$ & $\begin{array}{l}\text { "Manufacturers' engagement in various innovation activities to enhance customer satisfaction, including after-sale services, } \\
\text { warranty policy, maintenance routines, and order placement systems.” (p. 114) }\end{array}$ \\
\hline $\begin{array}{l}\text { Love, Roper, } \\
\text { and Hewitt- } \\
\text { Dundas (2010) }\end{array}$ & $\begin{array}{l}\text { Service } \\
\text { innovation }\end{array}$ & “New or significantly improved service” (p. 987) \\
\hline $\begin{array}{l}\text { Salunke, } \\
\text { Weerawardena, } \\
\text { and McColl- } \\
\text { Kennedy (2011) }\end{array}$ & $\begin{array}{l}\text { Service } \\
\text { innovation }\end{array}$ & $\begin{array}{l}\text { "As the extent to which new knowledge is integrated by the firm into service offerings, which directly or indirectly results in } \\
\text { value for the firm and its customers/clients." (p. 1253) }\end{array}$ \\
\hline Enz (2012) & $\begin{array}{l}\text { Service } \\
\text { innovation }\end{array}$ & $\begin{array}{l}\text { "The introduction of novel ideas that focus on services that provides new ways of delivering a benefit, new service concepts, or } \\
\text { new service business models through continuous operational improvement, technology, investment in employee performance, or } \\
\text { management of the customer experience.” (p.187) }\end{array}$ \\
\hline $\begin{array}{l}\text { Jian and Wang } \\
\text { (2013) }\end{array}$ & $\begin{array}{l}\text { Service } \\
\text { innovation }\end{array}$ & $\begin{array}{l}\text { "Enterprises' intangible activities formed in the process of service, using a variety of innovative ways to meet customer needs and } \\
\text { maintain competitive advantage." (p. 27) }\end{array}$ \\
\hline $\begin{array}{l}\text { Breunig et al. } \\
(2014)\end{array}$ & $\begin{array}{l}\text { Service } \\
\text { Innovation }\end{array}$ & $\begin{array}{l}\text { "New service experience or service solution that consists of one or several of the following dimensions: a new service concept, } \\
\text { new customer interaction, new value system/business partners, new revenue mode or new organizational or technological service } \\
\text { delivery system" (p.46) }\end{array}$ \\
\hline
\end{tabular}


Table 4 Centrality measures within demarcation

\begin{tabular}{|c|c|c|c|c|c|c|c|}
\hline \multicolumn{4}{|c|}{ Definition } & \multicolumn{4}{|c|}{ Full text } \\
\hline Term & Occurrences & Frequency & Centrality & Term & Occurrences & Frequency & Centrality \\
\hline Service & 56 & 1.22 & 6.18 & Service & 7642 & 166.13 & 4.03 \\
\hline New & 38 & 0.83 & 4.84 & Innovation & 5995 & 130.33 & 3.18 \\
\hline Change & 12 & 0.26 & 1.51 & Firm & 2211 & 48.07 & 1.19 \\
\hline Innovation & 18 & 0.39 & 1.38 & New & 2060 & 44.78 & 1.1 \\
\hline Customer & 15 & 0.33 & 1.37 & Market & 1761 & 38.28 & 0.94 \\
\hline Offer & 10 & 0.22 & 1.30 & Management & 1650 & 35.87 & 0.89 \\
\hline Firm & 12 & 0.26 & 1.23 & Customer & 1485 & 32.28 & 0.8 \\
\hline Process & 12 & 0.26 & 1.15 & Research & 1299 & 28.24 & 0.7 \\
\hline Product & 8 & 0.17 & 0.98 & Product & 1260 & 27.39 & 0.68 \\
\hline Market & 5 & 0.11 & 0.96 & Business & 1167 & 25.37 & 0.63 \\
\hline Introduce & 5 & 0.11 & 0.80 & Process & 1081 & 23.5 & 0.59 \\
\hline Organization & 5 & 0.11 & 0.77 & Performance & 917 & 19.93 & 0.5 \\
\hline Delivery & 5 & 0.11 & 0.76 & Value & 911 & 19.8 & 0.49 \\
\hline Technological & 4 & 0.09 & 0.75 & Model & 840 & 18.26 & 0.45 \\
\hline System & 6 & 0.13 & 0.74 & Capability & 747 & 16.24 & 0.4 \\
\hline Value & 8 & 0.17 & 0.71 & Development & 738 & 16.04 & 0.4 \\
\hline Result & 7 & 0.15 & 0.68 & Knowledge & 724 & 15.74 & 0.39 \\
\hline Organisational & 3 & 0.07 & 0.57 & Industry & 712 & 15.48 & 0.38 \\
\hline Offering & 5 & 0.11 & 0.56 & Strategy & 674 & 14.65 & 0.37 \\
\hline Development & 3 & 0.07 & 0.54 & Organization & 605 & 13.15 & 0.33 \\
\hline Previously & 4 & 0.09 & 0.53 & Resource & 599 & 13.02 & 0.32 \\
\hline Deliver & 4 & 0.09 & 0.53 & Technology & 571 & 12.41 & 0.31 \\
\hline Idea & 3 & 0.07 & 0.53 & Relationship & 560 & 12.12 & 0.30 \\
\hline Individual & 5 & 0.11 & 0.53 & Orientation & 549 & 11.75 & 0.29 \\
\hline Core & 2 & 0.04 & 0.52 & Innovative & 537 & 11.38 & 0.29 \\
\hline
\end{tabular}


Table 5 Definitions of service innovation from a synthesis perspective

\begin{tabular}{|c|c|c|}
\hline \multicolumn{3}{|r|}{ Synthesis } \\
\hline Source & Term & Definition \\
\hline $\begin{array}{l}\text { Gallouj and Weinstein } \\
\text { (1997) }\end{array}$ & Innovation & $\begin{array}{l}\text { “Any change affecting one or more terms of one or more vectors of characteristics (of whatever kind--technical, service or } \\
\text { competence)" (p. 547) }\end{array}$ \\
\hline $\begin{array}{l}\text { Van der Aa and Elfring } \\
\text { (2002) }\end{array}$ & Innovation & $\begin{array}{l}\text { "It encompasses ideas, practices, or objects which are new to the organization and to the relevant environment, that is to say to } \\
\text { the reference groups of the potential innovator." (p. 157) }\end{array}$ \\
\hline $\begin{array}{l}\text { Michel, Brown, and } \\
\text { Gallan (2008) }\end{array}$ & $\begin{array}{l}\text { Service-logic } \\
\text { innovation }\end{array}$ & “Finding new ways of co-solving customer problems.” (p. 50) \\
\hline Berry et al. (2010) & $\begin{array}{l}\text { Market-creating } \\
\text { Service innovation }\end{array}$ & $\begin{array}{l}\text { "An idea for a performance enhancement that customers perceive as offering a new benefit of sufficient appeal that it } \\
\text { dramatically influences their behavior, as well as the behavior of competing companies." (p.156) }\end{array}$ \\
\hline $\begin{array}{l}\text { Toivonen and } \\
\text { Tuominen (2009) }\end{array}$ & Service innovation & $\begin{array}{l}\text { "New service or such a renewal of an existing service which is put into practice and which provides benefit to the organisation } \\
\text { that has developed it; the benefit usually derives from the added value that the renewal provides the customers. In addition, to } \\
\text { be an innovation the renewal must be new not only to its developer, but in a broader context, and it must involve some element } \\
\text { that can be repeated in new situations, i.e. it must show some generalizable feature(s). "(p.893) }\end{array}$ \\
\hline $\begin{array}{l}\text { Ordanini and } \\
\text { Parasuraman (2011) }\end{array}$ & Service innovation & $\begin{array}{l}\text { "Offering not previously available to the firm's customers-either an addition to the current service mix or a change in the } \\
\text { service delivery process - that requires modifications in the sets of competences applied by service providers and/or customers" }\end{array}$ \\
\hline $\begin{array}{l}\text { Love, Roper, and } \\
\text { Bryson (2011) }\end{array}$ & Innovation & “The commercial application of new knowledge.” (p. 1438) \\
\hline $\begin{array}{l}\text { Cho, Park, and Kim } \\
\text { (2012) }\end{array}$ & Service innovation & "Introduction of new or significantly improved services and products.” (p. 377) \\
\hline $\begin{array}{l}\text { Santamaría, Nieto, and } \\
\text { Miles (2012) }\end{array}$ & Service innovation & $\begin{array}{l}\text { "New services have been introduced into the market, or (ii) existing services have been significantly improved or important } \\
\text { changes have been made to their basic characteristics, intangible components or desired purposes. (p.148)" }\end{array}$ \\
\hline Skålén et al. (2014) & Service innovation & $\begin{array}{l}\text { "The creation of new value propositions by means of developing existing or creating new practices and/or resources, or by } \\
\text { means of integrating practices and resources in new ways" (p. 137) }\end{array}$ \\
\hline
\end{tabular}


Table 6 Centrality measures within synthesis

\begin{tabular}{|c|c|c|c|c|c|c|c|}
\hline \multicolumn{4}{|c|}{ Definition } & \multicolumn{4}{|c|}{ Full text } \\
\hline Term & Occurrence & Frequency & Centrality & Term & Occurrence & Frequency & Centrality \\
\hline Service & 35 & 1 & 3.23 & Service & 10872 & 221.88 & 4.08 \\
\hline New & 34 & 0.97 & 2.78 & Innovation & 10109 & 206.31 & 3.81 \\
\hline Change & 11 & 0.31 & 1.4 & Firm & 3738 & 76.29 & 1.43 \\
\hline Customer & 13 & 0.37 & 1.36 & New & 2818 & 57.51 & 1.07 \\
\hline Product & 15 & 0.43 & 1.20 & Customer & 2329 & 47.53 & 0.89 \\
\hline Process & 12 & 0.34 & 1.18 & Process & 2169 & 44.27 & 0.83 \\
\hline Exist & 10 & 0.29 & 0.99 & Market & 2004 & 40.9 & 0.76 \\
\hline Innovation & 12 & 0.34 & 0.87 & Knowledge & 1775 & 36.22 & 0.67 \\
\hline Market & 9 & 0.26 & 0.82 & Product & 1661 & 33.9 & 0.64 \\
\hline More & 7 & 0.2 & 0.69 & Value & 1550 & 31.63 & 0.59 \\
\hline Value & 8 & 0.23 & 0.64 & Study & 1502 & 30.65 & 0.58 \\
\hline Benefit & 7 & 0.2 & 0.63 & Management & 1489 & 30.39 & 0.57 \\
\hline Characteristic & 5 & 0.14 & 0.59 & Business & 1486 & 30.33 & 0.57 \\
\hline Offer & 5 & 0.14 & 0.55 & Development & 1042 & 21.27 & 0.40 \\
\hline Firm & 6 & 0.17 & 0.54 & Industry & 1025 & 20.92 & 0.39 \\
\hline Idea & 5 & 0.14 & 0.53 & Activity & 920 & 18.78 & 0.36 \\
\hline Perceive & 4 & 0.11 & 0.53 & Manufactur & 908 & 18.53 & 0.35 \\
\hline Practice & 6 & 0.17 & 0.52 & Technology & 874 & 17.84 & 0.34 \\
\hline Create & 6 & 0.17 & 0.51 & Organization & 854 & 17.43 & 0.33 \\
\hline Develop & 5 & 0.14 & 0.5 & Change & 851 & 17.37 & 0.33 \\
\hline Element & 4 & 0.11 & 0.49 & Effect & 857 & 17.49 & 0.33 \\
\hline Significantly & 5 & 0.14 & 0.45 & Develop & 821 & 16.76 & 0.32 \\
\hline Behavior & 4 & 0.11 & 0.42 & Organization & 854 & 17.43 & 0.33 \\
\hline Performance & 4 & 0.11 & 0.42 & Change & 851 & 17.37 & 0.33 \\
\hline Improve & 5 & 0.14 & 0.42 & Effect & 857 & 17.49 & 0.33 \\
\hline
\end{tabular}


Table 7 Overview of how the three perspectives of service innovation define service innovation

\begin{tabular}{|c|c|c|c|}
\hline & Assimilation & Demarcation & Synthesis \\
\hline Description & $\begin{array}{l}\text { A perspective of service innovation } \\
\text { suggesting that knowledge on product } \\
\text { innovation holds for all types of offerings. }\end{array}$ & $\begin{array}{l}\text { A perspective of service innovation } \\
\text { suggesting that innovation in service } \\
\text { industries is unique and needs to be } \\
\text { treated different from other types of } \\
\text { offerings. }\end{array}$ & $\begin{array}{l}\text { A perspective of service innovation } \\
\text { suggesting that service as a perspective } \\
\text { can be used to understand innovation } \\
\text { in all types of offerings. }\end{array}$ \\
\hline Core concept & Innovation & Services innovation & Service Innovation \\
\hline $\begin{array}{l}\text { Key characteristics } \\
\text { (Def.) }\end{array}$ & $\begin{array}{l}\text { Product, Process, Organization, } \\
\text { Significantly }\end{array}$ & Change, Customer, Offer, Firm & $\begin{array}{l}\text { Change, Customer, Product, Process, } \\
\text { Exist, More, Value }\end{array}$ \\
\hline $\begin{array}{l}\text { Service innovation as } \\
\text { a process or outcome }\end{array}$ & Outcome & Outcome & Process and outcome \\
\hline $\begin{array}{l}\text { Invention versus } \\
\text { innovation }\end{array}$ & Innovation & Invention & Invention \\
\hline New for whom & World & Firm & Firm \\
\hline $\begin{array}{l}\text { Exchange value } \\
\text { versus use value }\end{array}$ & Exchange value & Use value & Use value \\
\hline Core references & Ko and Lu (2010), Pearson (1997) & $\begin{array}{l}\text { Den Hertog, Van der Aa, and Jong } \\
\text { (2010), Agarwal and Selen (2009) }\end{array}$ & $\begin{array}{l}\text { Gallouj and Weinstein (1997), Sundbo } \\
\text { (1997), Drejer (2004) }\end{array}$ \\
\hline
\end{tabular}

